\title{
Leaf life spans of some conifers of the temperate forests of South America
}

\author{
Longevidad foliar de algunas coníferas de los bosques templados de Sudamérica
}

\author{
CHRISTOPHER H. LUSK \\ Departamento de Botánica, Universidad de Concepción, Casilla 160-C, Concepción, Chile \\ e-mailclusk@udec.cl
}

\begin{abstract}
Interspecific variation in leaf life span has wide-ranging implications for plant species sorting on resource availability gradients, and for ecosystem processes such as nutrient cycling. Very little is known about leaf life spans of evergreen trees in the temperate forests of South America. Leaf life spans were estimated by static demographic methods, and associated leaf traits measured, for four conifers of this region. It was expected that leaf life span variation would correlate negatively with soil fertility of habitats normally occupied by each species. This prediction was upheld by the data. The mean leaf life span determined for Araucaria araucana (24 years) is among the highest figures reported for any plant species. This extreme leaf longevity was associated with very robust construction (high leaf mass per unit area) and very low nitrogen content. These aspects of the ecology of $A$. araucana may affect its fitness in two ways. Firstly, slow foliage turnover will reduce its annual nutrient requirements for crown maintenance, a trait that is thought to be crucial for survival on nutrient-poor sites. Secondly, the low decomposability of $A$. araucana leaf litter is likely to cause nutrient immobilisation, possibly favouring site retention by A. araucana in the face of competition from faster-growing but more nutrient-demanding species. Interspecific variation in leaf life span appeared to be systematically related to variation in leaf mass per unit area (LMA) and leaf nitrogen, in agreement with a large body of evidence that leaf evolution is constrained by a trade-off between trait combinations which optimise carbon gain and growth in resourcerich habitats, and those which favour persistence in chronically adverse environments.
\end{abstract}

Key words: Araucaria araucana, leaf longevity, leaf nitrogen, Podocarpus, resource gradients, specific leaf area.

\section{RESUMEN}

Las diferencias específicas en longevidad foliar tienen importantes implicancias para la distribución de las plantas en relación con gradientes de recursos, y en procesos ecosistémicos tales como el ciclaje de nutrientes. Se conoce muy poco acerca de la longevidad foliar de las especies arbóreas siempreverdes de los bosques templados de Sudamérica. Se estimaron longevidades foliares mediante métodos demográficos "estáticos" para cuatro especies de coníferas de esta región; además se midieron otros rasgos foliares (masa seca por unidad de area = "LMA", y contenido de nitrógeno). Se anticipó que las diferencias interespecíficas en longevidad foliar estarían negativamente correlacionadas con la disponibilidad de nutrientes en los hábitats normalmente ocupados por las distintas especies, predicción que fue apoyada por los datos. La longevidad foliar promedio determinada para Araucaria araucana (24 años) se destaca entre las cifras más altas reportadas en la literatura para cualquier especie. Esta extrema longevidad se asocia con una construcción muy robusta (LMA alta), y muy bajo contenido de nitrógeno. Dichos aspectos de la ecología de $A$. araucana podrían incidir de dos maneras en su adecuación. Primero, el lentísimo recambio de su follaje reduciría sus requerimientos anuales de nutrientes, un rasgo que puede ser clave para su supervivencia en sitios muy infértiles. Segundo, la baja descomposabilidad de su hojarasca daría lugar a una inmovilización de nutrientes, posiblemente permitiendo que $A$. araucana retenga ciertos sitios, frente la competencia de especies potencialmente más vigorosas pero con mayores requerimientos nutricionales. La variación interespecífica en longevidad foliar parecía presentar relaciones estrechas con variación en LMA y porcentaje de nitrógeno foliar. Dicho resultado es coherente con las evidencias arrojadas por otros estudios, que indican que la evolución de las hojas estaría restringida por un compromiso entre combinaciones de rasgos que optimizan el rendimiento de la planta en hábitats favorables, y aquellas combinaciones que favorecen la persistencia en hábitats adversos.

Palabras clave: Araucaria araucana, área foliar específica, gradientes de recursos, longevidad foliar, nitrógeno foliar, Podocarpus. 


\section{INTRODUCTION}

The ecological correlates and adaptive significance of variation in leaf life span have received considerable attention during the past two decades. The earliest interpretations focused on the deciduous/ evergreen dichotomy, and emphasised selective pressures imposed by climate (Bailey \& Sinnott 1916, Axelrod 1966). More recent work has recognised that leaf life spans vary continuously over about 2.5 orders of magnitude, and has suggested that this trait also plays a central role in plant adaptation to resource availability (Monk 1966, Chabot \& Hicks 1982, Reich 1993, Aerts 1995).

Long leaf life spans are common in plants native to habitats where chronically low resource availabilities severely constrain carbon gain and growth. The simplest general explanation of this trend is that leaves take longer to amortise their construction costs in unproductive habitats (Orians \& Solbrig 1977, Chabot \& Hicks 1982), with resulting selection for longer functional life spans. For example, in evergreen forests, slow foliage turnover is common in shade-tolerant species that establish in shaded late-successional environments (Williams et al. 1989, King 1994, Reich et al. 1995a, Lusk \& Contreras 1999). Although payback times are also probably relevant to the prevalence of long-lived leaves on infertile soils, the advantage in conserving scarce nutrients may be at least as important (Aerts 1995). As leaf litterfall is generally the most important route of nutrient loss from perennials (Eckstein \& Karlsson 1997), slow foliage turnover is probably the most powerful nutrient conservation mechanism available to such plants (Escudero et al. 1992).

Prolongation of functional life span requires that the leaf be robustly constructed (high fibre content, high dry mass to area ratio), and rendered unattractive to herbivores by toughness, low nutritional value and/or chemical deterrents (Coley et al. 1985, Reich 1993). However, this type of construction implies dilution of the photosynthetic machinery by leaf structural components, and a low rate of photosynthetic return per unit of biomass invested in leaf tissue. Hence evolution of leaf structure and function is constrained by a trade-off between performance and persistence (Berendse \& Aerts 1987, Reich 1993). In habitats where rapid growth is important to plant fitness (i.e., habitats with abundant light, water and nutrients), there should therefore be indirect selection for short leaf life spans. The universality of the performance-persistence trade-off is demonstrated by the minimal influence of phylogeny on correlations among leaf structural and functional traits (Ackerly \& Reich 1999).
Although conifers retain their leaves for longer on average than angiosperms, the former group encompasses an enormous range of variation in leaf life spans, from 6 months to more than 40 years (Reich et al. 1995b). Very little is known about leaf life spans of the conifers of the temperate forests of South America. In this short communication, I present data on life spans and associated traits of leaves of four "broadleaved" conifer species from this region, i.e. species with flattened, non-imbricate leaves. In keeping with what is known about ecological correlates of leaf traits, we expected that interspecific variation would show a negative relationship with soil fertility in the habitats normally occupied by each species.

An additional motive for this study was the suspicion that one of the species studied (Araucaria araucana (Molina) Koch) might exhibit one of the longest leaf life spans reported for plants of any kind. Green leaves are often present at distances of several metres from the apex of $A$. araucana stems and branches, suggesting accumulation of many growing seasons' foliage production. Great longevity of A. araucana leaves is also suggested by their extremely robust construction (cf. Reich 1993).

\section{MATERIAL AND METHODS}

The study included the three most widely-distributed conifer species of the temperate rainforests of south-central Chile (Podocarpus saligna D.Don, P. nubigena Lindl., Saxegothaea conspicua Lindl.), as well as Araucaria araucana, a species with a more restricted distribution. The autoecology of these species has not received a great deal of study, but differences in site requirements are apparent from their respective distributions on regional and fine-scale environmental gradients (Veblen et al. 1981, Veblen et al. 1995, Lusk 1996). Podocarpus saligna was sampled on the eastern slopes of Cordillera Pelada, at an altitude of ca. $400 \mathrm{~m}$ (latitude ca. $40^{\circ} \mathrm{S}$ ). Podocarpus nubigena and $S$. conspicua were sampled on the summit plateau of the same range, at an altitude of ca. $900 \mathrm{~m}$. Araucaria araucana was sampled on the western slopes of Cordillera de Nahuelbuta, at an altitude of ca. 1,000 m (latitude ca. $38^{\circ} \mathrm{S}$ ).

Leaf life spans are often studied by marking a population of leaves (typically, all the leaves on a small branch), and monitoring survivorship (e.g., Williams et al. 1989, King 1994). In some plants, leaf life span can also be inferred instantaneously from leaf population structure, using methods 
similar to those of a static life table. Many Podocarpaceae, including all three species included in this study, produce clear resting bud scars, permitting ready delimitation of recent years' shoot extension growth, and ageing of leaf cohorts. Destructive sampling of a sub-sample (n $=5$ ) of each species confirmed a one-to-one relationship between the number of growth rings present in a branch cross-section and the number of resting bud scars. For these three species, average leaf life span was estimated by determining the relative abundance of surviving leaves and abscission scars for successively older cohorts, until reaching a leaf cohort $x$ that had sustained ca. $50 \%$ mortality (Fig. 1). As sampling was carried out in autumn, at the end of the growing season, the mean leaf life span for each sampled individual was estimated as $x-0.5$; i.e., the youngest leaf cohort was considered to be on average about 6 months old, rather than a full year. This procedure was performed on one branch of each of 12 juvenile trees ( 1.5 to $4 \mathrm{~m}$ tall) of each species. We constrained the influence of light environment on leaf traits by sampling only individuals growing beneath small canopy openings of approximately 5-10 m diameter.

Araucaria araucana, on the other hand, does not produce resting bud scars, so leaf age cannot be readily determined by external inspection. A dendroecological variant of the same "static" ap- proach was therefore used for this species. The stems of juvenile A. araucana (3-6 m tall) were inspected from the top downwards, until reaching a region where c. $50 \%$ of leaves had died. An increment core was then extracted at this level, to permit determination of stem (and hence leaf) age at that height. Cores were mounted, dried and polished with progressively finer sandpaper (to 400-grit) to produce a surface suitable for counting growth rings, which were assumed to be annual (La Marche et al. 1979, Holmes 1982, Villalba $\&$ Boninsegna 1992). In contrast to the other three species, we sampled $A$. araucana in two light environments: 12 open-grown individuals in large gaps, and 12 individuals growing beneath a light canopy of Nothofagus dombeyi (Mirb) Blume and N. obliqua (Mirb.) Oerst. This enabled an analysis of the influence of light environment on leaf life-span in this species. For the purposes of interspecific comparisons, the average of these two extremes (full sun vs. shade) was assumed to be comparable to the intermediate light environments in which the other three species were sampled.

Interspecific variation in leaf life span is often associated with parallel variation in other leaf traits which influence durability and palatability, such as leaf mass per unit area (LMA) and nitrogen content (Reich 1993). These parameters were therefore also measured for each species. LMA

\section{Leaf cohort ages (years)}

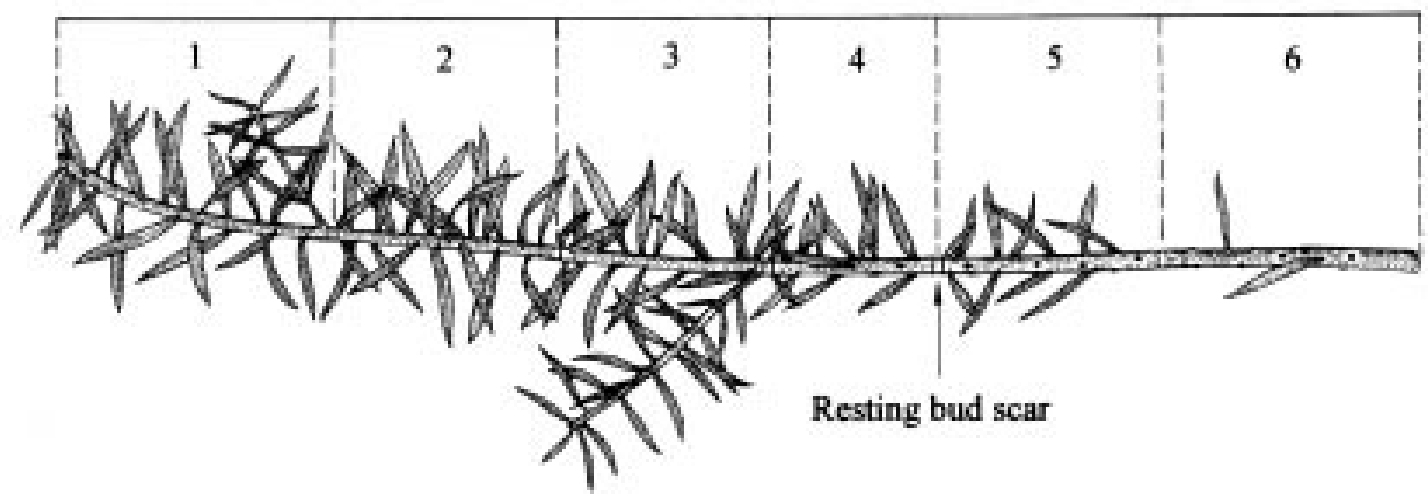

Fig. 1: Branchlet of Podocarpus nubigena, showing resting bud scars delimiting successive leaf cohorts. Average leaf life span is estimated from past mortality rates, evident from relative abundance of surviving leaves and abscission scars for successive cohorts. Leaf population structure on this branchlet would suggest a mean life span of ca. 5 years, as about $50 \%$ of leaves from the $5^{\text {th }}$ most-recent cohort have died.

Esquema de ramilla de Podocarpus nubigena, mostrando las cicatrices de catáfilos que delimitan las cohortes foliares sucesivas. La longevidad foliar promedio se estima sobre la base de las tasas de mortalidad que se evidencian de la abundancia relativa de hojas sobrevivientes y las cicatrices de abscisión en cada cohorte. La demografía foliar de esta ramilla sugeriría una longevidad promedio de ca. 5 años, dado que ha muerto alrededor del $50 \%$ de las hojas de la cohorte de hace 5 temporadas. 
was calculated by removing a sample of 10 to 20 mature leaves from each of four individuals of each species, measuring their total area with an LI-COR 3000 leaf area meter, and then determining dry weight. Total nitrogen was determined for the same four samples by the Kjeldahl method.

All statistical analyses were carried out using JMP Statistical Software (SAS Institute).

\section{RESULTS}

\section{Leaf life spans}

Mean leaf life spans ranged from $c a .3$ years in Podocarpus saligna to ca. 24 years in Araucaria araucana (Table 1). Leaf life span of $A$. araucana was significantly influenced by light environment, the mean for shaded individuals being $>20$ $\%$ higher than that for well-lit trees (Student ttest, $\mathrm{P}=0.01$, Table 1 ).

\section{Relationships with other leaf traits}

Mean leaf life span data were log-transformed to normalise their distribution. Interspecific variation in leaf life span appeared to be positively related to LMA (Fig. 2), and negatively so with leaf $\mathrm{N}$ concentration (Table 1 and Fig. 3). However, despite high $\mathrm{R}^{2}$ values, neither of these correlations was statistically significant at $\mathrm{P}=$ 0.05. There was, however, a highly significant negative correlation between LMA and leaf $\mathrm{N}$ (Fig. 4).

Shaded individuals of $A$. araucana produced significantly thinner leaves than well-lit conspecifics, i.e., LMA was significantly lower in the shade (Student t-test, $\mathrm{P}=0.014$, Table 1 ).

\section{DISCUSSION}

Leaf life spans of broadleaved conifers of the temperate forests of South America (3-24 years) are generally higher than those found for associated evergreen angiosperms (1-4.5 years) (Lusk \& Contreras 1999), but occupy a similar range to data reported for North American species of Pinus (Ewers \& Schmid 1981).

As expected, interspecific variation in leaf life spans showed a fairly close relationship with soil fertility in the environments normally occupied by the respective species. The extremely slow foliage turnover of Araucaria araucana (Table 1) may be an important determinant of its ability to colonise raw volcanic ash and lava flows (Veblen 1982), where availability of some nutrients, especially nitrogen, is initially very low (cf. Del Moral $\&$ Bliss 1993). At the other extreme, the relatively rapid foliage turnover of Podocarpus saligna correlates with its occurrence on deep, fertile soils in the central depression and on the lower slopes of both ranges in south-central Chile, where plant fitness is probably more closely-

TABLE 1

Leaf traits of four conifers of the temperate forests of South America. All data are from juvenile trees, and, with the exception of A. araucana, all sampled individuals were growing beneath small canopy openings. Species means followed by the same letter are not significantly different at $\mathrm{P}=0.05$ (Tukey-Kramer HSD test)

Rasgos foliares para cuatro coníferas de los bosques templados de Sudamérica. Todos los datos provienen de árboles juveniles, y todos con la excepción de A. araucana son de individuos encontrados bajo claros pequeños. Los promedios específicos que compartan la misma letra en superíndice no difieren significativamente $(\mathrm{P}=0,05$, prueba de Tukey-Kramer HSD)

\begin{tabular}{|c|c|c|c|c|}
\hline Species & & $\begin{array}{l}\text { Life span } \\
\text { (years) }\end{array}$ & $\begin{array}{c}\text { LMA } \\
\left(\mathrm{g} \mathrm{m}^{-2}\right)\end{array}$ & $\begin{array}{c}\text { Total nitrogen } \\
(\%)\end{array}$ \\
\hline \multirow[t]{3}{*}{ Araucaria araucana } & Open & $21.5 \pm 1.2$ & $370.0 \pm 17.8$ & - \\
\hline & Shade & $26.2 \pm 1.2$ & $266.1 \pm 17.8$ & - \\
\hline & Average & $23.9 \pm 0.9^{a}$ & $318.0 \pm 25.8^{\mathrm{a}}$ & $0.58 \pm 0.07^{a}$ \\
\hline Podocarpus nubigena & & $7.3 \pm 0.4^{b}$ & $204.6 \pm 10.2^{b}$ & $0.92 \pm 0.05^{b}$ \\
\hline Saxegothaea conspicua & & $4.2 \pm 0.3^{c}$ & $133.0 \pm 7.2^{\mathrm{c}}$ & $1.07 \pm 0.03^{b}$ \\
\hline Podocarpus saligna & & $3.2 \pm 0.2^{c}$ & $176.9 \pm 6.7^{b}$ & $0.93 \pm 0.08^{b}$ \\
\hline
\end{tabular}




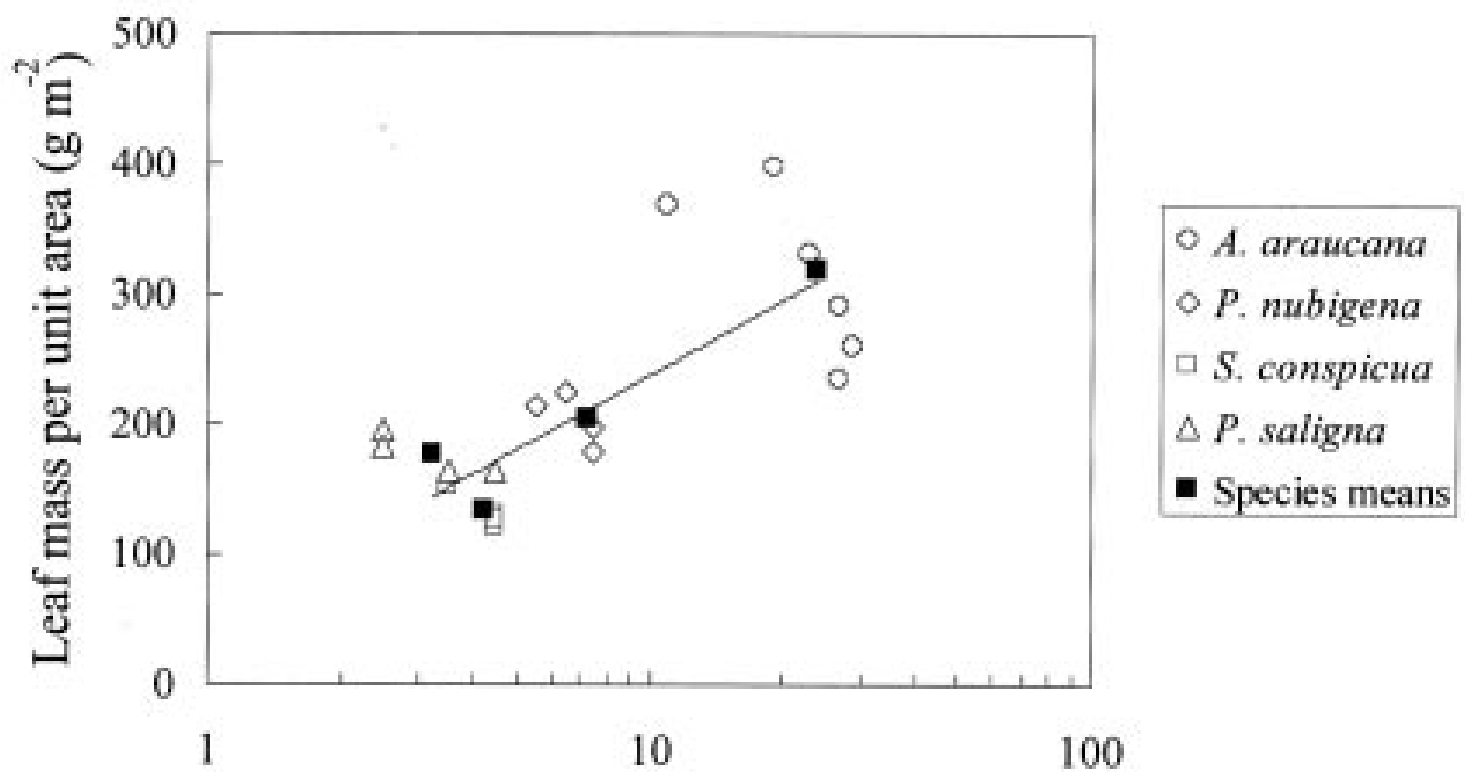

\section{Leaf lifespan (years)}

Fig. 2: Relationship of leaf life span with leaf mass per unit area (LMA) for four conifers of the temperate forests of South America, with a different symbol for each species. Fitted line is for means of the four species $\left(\mathrm{R}^{2}=0.88, \mathrm{P}=0.06\right)$.

Relación entre longevidad foliar y masa seca por unidad de área foliar (LMA), para cuatro coníferas de los bosques templados de Sudamérica, con un símbolo distinto para cada especie. La línea muestra la relación interespecífica, usando los promedios de las cuatro especies $\left(\mathrm{R}^{2}=0,88, \mathrm{P}=0,06\right)$.

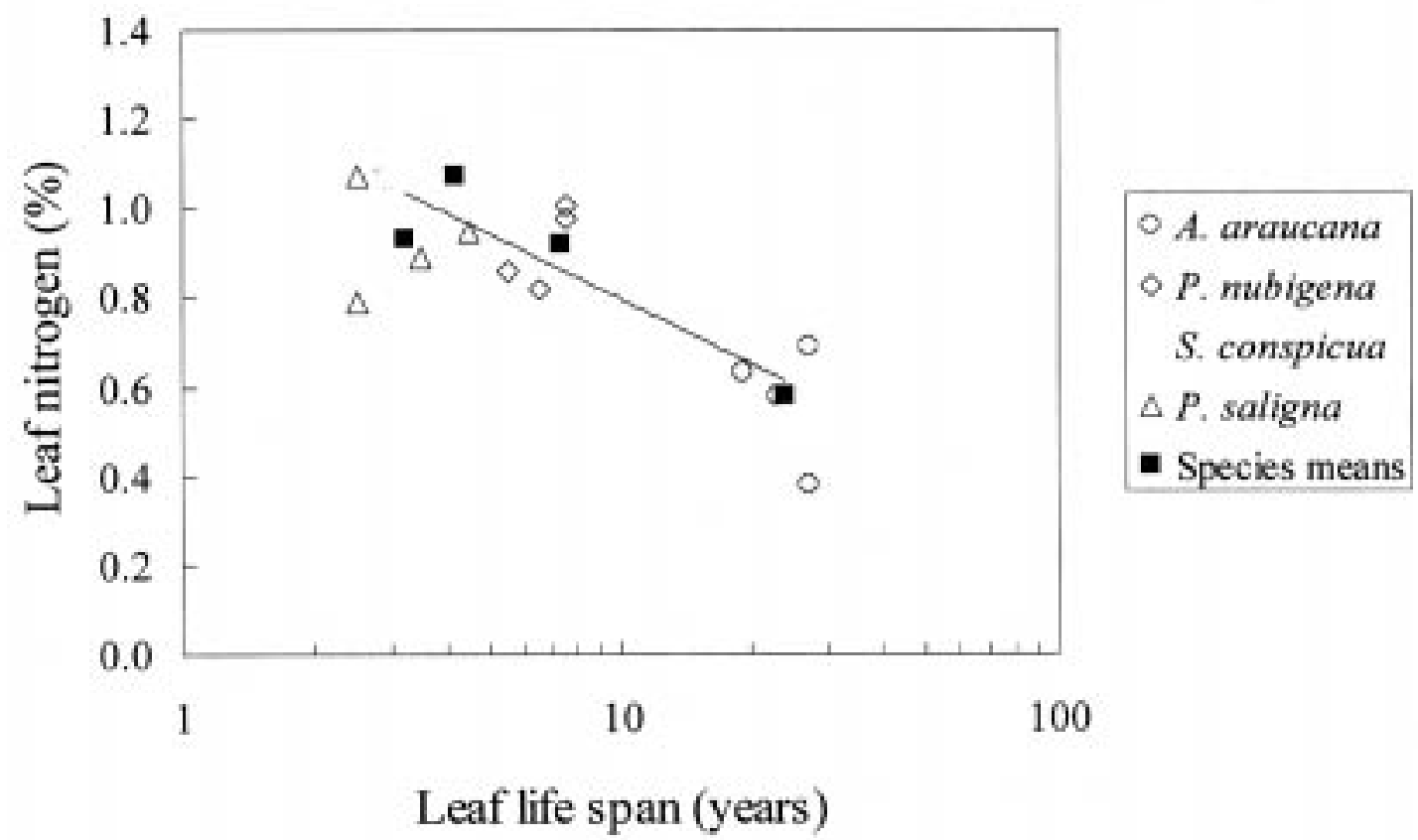

Fig. 3: Relationship of leaf life span with leaf nitrogen concentration for four temperate South American conifers, with a different symbol for each species. Fitted line is for means of the four species $\left(\mathrm{R}^{2}=0.83\right.$, $\mathrm{P}=0.09$ ).

Relación entre longevidad y nitrógeno foliares, para cuatro coníferas de los bosques templados de Sudamérica, con un símbolo distinto para cada especie. La línea muestra la relación interespecífica, usando los promedios de las cuatro especies $\left(\mathrm{R}^{2}=0,83, \mathrm{P}=0,09\right)$. 


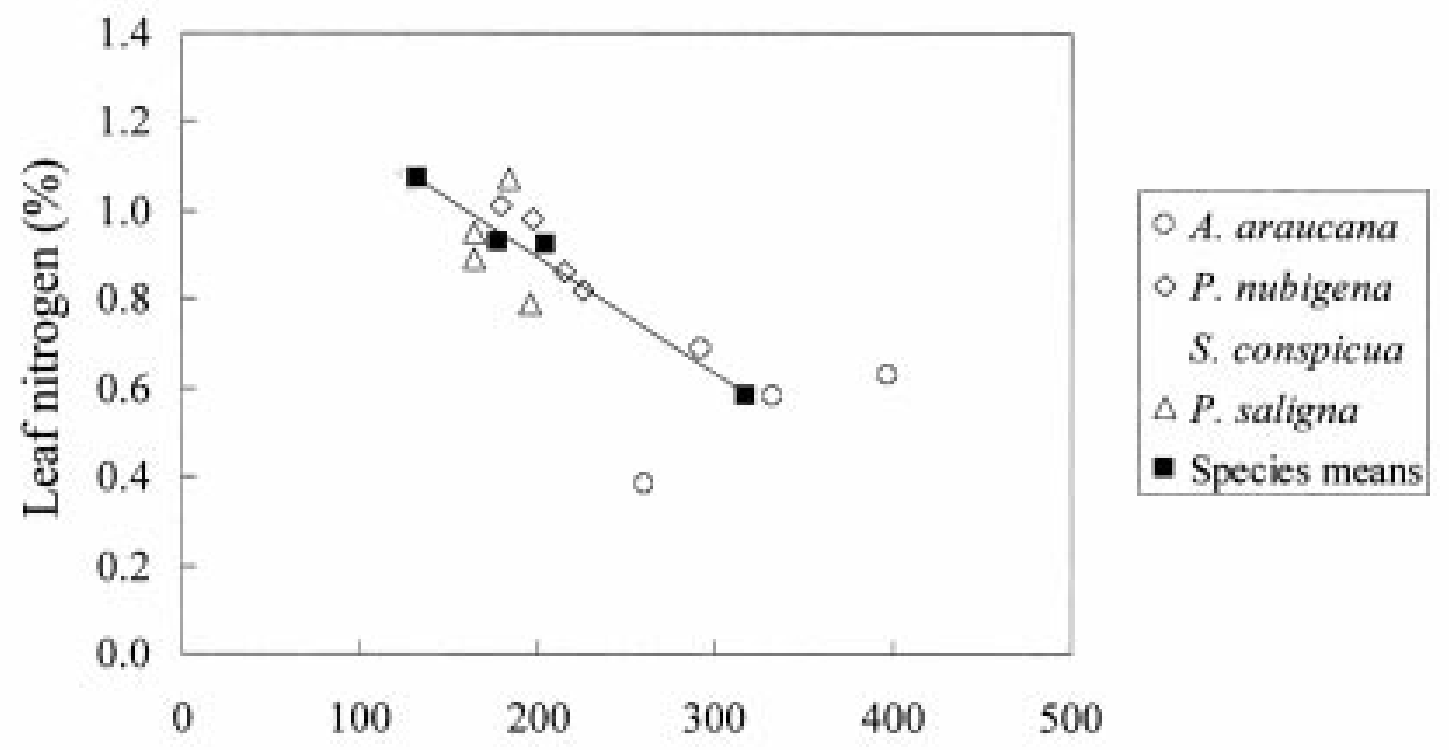

\section{Leaf mass per unit area $\left(\mathrm{g} \mathrm{m}^{-2}\right)$}

Fig. 4: Relationship of leaf mass per unit area (LMA) with leaf nitrogen concentration for four temperate South American conifers, with a different symbol for each species. Fitted line is for means of the four species $\left(\mathrm{R}^{2}=0.99, \mathrm{P}=0.007\right)$.

Relación entre masa seca por unidad de área foliar (LMA) y nitrógeno foliar (\% N), para cuatro coníferas de los bosques templados de Sudamérica, con un símbolo distinto para cada especie. La línea muestra la relación interespecífica, usando los promedios de las cuatro especies $\left(\mathrm{R}^{2}=0,99, \mathrm{P}=0,007\right)$.

related to growth rates than to nutrient conservation.

Saxegothaea conspicua and P. nubigena grow at higher altitudes than $P$. saligna, where a higher ratio of precipitation to evapotranspiration is likely to result in greater nutrient leaching, and hence lower soil fertility. Although the distributions of these two species overlap considerably, S. conspicua tends to grow on more fertile, betterdrained soils than P. nubigena (Lusk 1996), once again correlating with leaf life span differences (Table 1).

As anticipated, the mean leaf longevity estimated for A. araucana (24 years) is one of the highest figures reported in the literature. The highest reliably-documented leaf life span of any plant is ca. 40 years in some high-altitude populations of Pinus longaeva, although figures of 10-20 years appear to be more typical of this species (Ewers \& Schmid 1981). It seems reasonable to suggest that leaf life spans in excess of 30 years could be found in $A$. araucana populations on sites at higher altitudes, as a number of other studies of intraspecific variation in evergreen species have demonstrated significant positive correlations of leaf life span with altitude or latitude (Ewers \& Schmid 1981, Reich et al. 1995b).
The phenomenon of branch abscission in $A$. araucana may cause overall foliage turnover rates to differ from the figures calculated in the present study. The present analysis assumes that leaves die individually, but A. araucana, like other Araucariaceae (Silvester \& Orchard 1999), often sheds whole branchlets. As branch abscission involves loss of young leaves as well as older ones, this phenomenon will cause the method used here to overestimate overall leaf life spans, although the magnitude of this error is unknown.

Environmental controls on amortisation rates, thought to exert strong selection pressure on genotypic variation in leaf longevity, could also control intraspecific variation in leaf retention time. The responsiveness of $A$. araucana leaf life spans to light environment (Table 1) could indicate phenotypic adjustment of leaf life span to lower carbon gain rates, and hence longer payback times, in shaded environments. The influence of growth rates on self-shading provides another possible explanation for the effect of light environment. Self-shading is known to influence leaf life spans (Ackerly \& Bazzaz 1995), and light environments of old leaves are likely to change more gradually in slow-growing, shaded, individuals of $A$. araucana than in open-grown 
ones. Height growth data from the same trees examined in the present study confirm markedly slower growth in shaded $A$. araucana than in open-grown trees (Lusk \& Le-Quesne 2000).

The structural and biochemical characteristics that prolong the life of $A$. araucana leaves, by increasing physical resistance and reducing palatability (high LMA and low $\mathrm{N}$ content), are also likely to influence decomposition and nutrient cycling, and this may have consequences for competitive interactions with other species (Berendse 1994). Although no decomposition data are available for this species, litter decomposition rates in general are positively correlated with $\mathrm{N}$ content and negatively so with LMA (Lambers et al. 1998). Where A. araucaria occurs with faster-growing but more nutrient-demanding species, low decomposability of A. araucana leaf litter could reduce soil nutrient availability through immobilisation, possibly depressing the the vigour and survivorship of its competitors, and increasing the probability of long-term site retention by A. araucana (cf. Berendse 1994).

The leaf life span data presented here confound possible environmental effects with inherent species differences, as, despite the effort to standardise light environments, the four species were sampled on sites that differ in altitude and latitude. However, the observed interspecific differences in leaf life span showed a marginally significant correlation with variation in LMA, a parameter which, although highly influenced by light environment (Table 1), is much less sensitive to inherent site differences in factors such as temperature and rainfall (e.g., Gutiérrez et al. 1991). The overall relationships between leaf $\mathrm{N}$, life span, and LMA (Fig. 2-4) suggest that environmentally-controlled variation in leaf life spans in the data set is secondary to inherent species differences. This is in agreement with a body of evidence that leaf evolution is strongly constrained by a trade-off between those trait combinations which optimise carbon gain and growth in resource-rich habitats (low LMA, high leaf N) and those which favour persistence in chronically adverse environments (slow foliage turnover, high LMA, low leaf N) (Berendse \& Aerts 1987, Reich 1993, Ackerly \& Reich 1999).

\section{ACKNOWLEGMENTS}

Agradezco a Olga Contreras y Carlos Le-Quesne por su ayuda y grata compañía en terreno, a Alfredo Saldaña por sus correcciones al Castellano, y a un árbitro anónimo por sus sugerencias constructivas.

\section{LITERATURE CITED}

ACKERLY DD \& FA BAZZAZ (1995) Leaf dynamics, self-shading and carbon gain in seedlings of a tropical pioneer tree. Oecologia 101: 289-298.

ACKERLY DD \& PB REICH (1999) Convergence and correlations among leaf size and function in seed plants: a comparative test using independent contrasts. American Journal of Botany 86: 1272-1281.

AERTS R (1995) The advantages of being evergreen. Trends in Ecology and Evolution 10: 402-407.

AXELROD DI (1966) Origin of deciduous and evergreen habits in temperate forests. Evolution 20: 1-15.

BAILEY IW \& EW SINNOTT (1916) The climatic distribution of certain types of angiosperm leaves. American Journal of Botany 3: 24-39.

BERENDSE F (1994) Litter decomposability - a neglected component of plant fitness. Journal of Ecology 82: 187-190.

BERENDSE F \& R AERTS (1987) Nitrogen-use efficiency: a biologically meaningful definition? Functional Ecology 1: 293-296.

CHABOT BF \& DJ HICKS (1982) The ecology of leaf life spans. Annual Review of Ecology and Systematics 13: 229-259.

COLEY PD, JP BRYANT \& FS CHAPIN (1985) Resource availability and plant anti-herbivore defence. Science 230: 895-899.

DEL MORAL R \& LC BLISS (1993) Mechanisms of primary succession: insights resulting from the eruption of Mt. St. Helens. Advances in Ecological Research 24: 1-66.

ECKSTEIN RL \& PS KARLSSON (1997) Above-ground growth and nutrient use by plants in a subarctic environment: effects of habitat, life-form and species. Oikos 79: 311-324.

ESCUDERO A, JM DEL ARCO, IC SANZ \& MV GARRIDO (1992) Effects of leaf longevity and retranslocation efficiency on the retention time of nutrients in the leaf biomass of different woody species. Oecologia 90: 80-87.

EWERS FW \& R SCHMID (1981) Longevity of needle fascicles of Pinus longaeva (Bristlecone Pine) and other North American pines. Oecologia 51: 107-115.

GUTIÉRREZ E, R VALLEJO, J ROMAÑA \& J FONS (1991) The subantarctic Nothofagus forests of Tierra del Fuego: distribution, structure and production. Oecologia Aquatica 10: 351-366.

HOLMES RL (1982) Argentina and Chile. In: Hughes MK, PM Kelly, JR Pilcher \& VC La Marche (eds) Climate from tree-rings: 84-89. Cambridge University Press, Cambridge, England.

KING DA (1994) Influence of light level on growth and morphology of saplings in a Panamanian forest. American Journal of Botany 81: 948-957.

LA MARCHE VC, RL HOLMES, PW DUNWIDDIE \& LG DREW (1979) Tree-ring chronologies of the Southern Hemisphere. Chronology Series V, Volume 2: Chile. University of Arizona, Tucson, Arizona. 43 pp.

LAMBERS H, FS CHAPIN \& TL PONS (1998) Plant physiological ecology. Springer-Verlag, New York, New York. 540 pp. 
LUSK C (1996) Gradient analysis and disturbance history of temperate rain forests of the coast range summit plateau, Valdivia, Chile. Revista Chilena de Historia Natural 69: 401-411.

LUSK C \& O CONTRERAS (1999) Foliage area and crown nitrogen turnover in juvenile rainforest trees of differing shade tolerance. Journal of Ecology 87: 973-983.

LUSK C \& C LE-QUESNE (2000) Branch whorls of juvenile Araucaria araucana (Molina) Koch: are they formed annually? Revista Chilena de Historia Natural 73: 497-502.

MONK CD (1966) An ecological significance of evergreenness. Ecology 47: 504-505.

ORIANS GH \& OT SOLBRIG (1977) A cost-income model of leaves and roots with special reference to arid and semi-arid areas. American Naturalist 134: 90-98.

REICH PB (1993) Reconciling apparent discrepancies among studies relating life-span, structure and function of leaves in contrasting life-forms and climates: "the blind men and the elephant retold". Functional Ecology 7: 721-725.

REICH PB, DS ELLSWORTH \& C UHL (1995a) Leaf carbon and nutrient assimilation and conservation in species of differing successional status in an oligotrophic Amazonian forest. Functional Ecology 9: 65-76.

REICH PB, T KOIKE, ST GOWER \& AW SCHOETTLE (1995b) Causes and consequences of variation in conifer leaf life-span. In: Smith WK \& TM Hinkley (eds) Ecophysiology of coniferous forests: 225-253. Academic Press, San Diego, California.

Associate Editor: J. Armesto

Received August 10, 1999; accepted June 1, 2001
SILVESTER WB \& TA ORCHARD (1999) The biology of kauri (Agathis australis) in New Zealand. I. Production, biomass, carbon storage and litter fall in four forest remnants. New Zealand Journal of Botany 37: 553-571.

VEBLEN TT (1982) Regeneration patterns in Araucaria araucana forests in Chile. Journal of Biogeography 9: 11-28.

VEBLEN TT, C DONOSO, FM SCHLEGEL \& B ESCOBAR (1981) Forest dynamics in south-central Chile. Journal of Biogeography 8: 211-247.

VEBLEN TT, BR BURNS, T KITZBERGER, A LARA \& R VILLALBA (1995) The ecology of the conifers of southern South America. In: Enright NJ \& RS Hill (eds) Ecology of the southern conifers: 120-155. Melbourne University Press, Melbourne, Australia.

VILLALBA R \& JA BONINSEGNA (1992) Changes in southern South American tree-ring chronologies following major volcanic eruptions between 1750 and 1970. In: Harrington CR (ed) The year without a summer? world climate in 1816: 493-509. Canadian Museum of Nature, Ottawa, Ontario.

WILLIAMS KC, CB FIELD \& HA MOONEY (1989) Relationships among leaf construction cost, leaf longevity and light environment in rain-forest plants of the genus Piper. American Naturalist 133: 198-211. 